\title{
$\begin{array}{lllllllllllllllll}\mathbf{R} & \mathbf{O} & \mathbf{Z} & \mathbf{P} & \mathbf{R} & \mathbf{A} & \mathbf{W} & \mathbf{Y} & \mathbf{I} & \mathbf{A} & \mathbf{R} & \mathbf{T} & \mathbf{Y} & \mathbf{K} & \mathbf{U} & \mathbf{L} & \mathbf{Y}\end{array}$
}

Prawo Kanoniczne 58 (2015) nr 3

O. TOMASZ GAŁKOWSKI C.P.

Wydział Prawa Kanonicznego

Uniwersytetu Kardynała Stefana Wyszyńskiego w Warszawie

\section{DYLEMATY WOKÓŁ USTAWY KANONICZNEJ (I) - ORDINATIO RATIONIS CZY FIDEI W ŚWIETLE ENCYKLIKI FIDES ET RATIO}

Treść: Wprowadzenie. - 1. Za i przeciw Tomaszowej definicji ustawy podczas prac nad rewizją KPK. - 2. Krytyka aplikacji definicji ustawy Tomasza do prawa kanonicznego. - 3. Obecne definicje ustawy kanonicznej. - 4. Ordinatio rationis w definicji ustawy Tomasza. -5 . Fides et ratio we wzajemnych relacjach. - Zakończenie.

\section{Wprowadzenie}

Brak jasno określonej i powszechnie akceptowanej definicji ustawy kanonicznej jest jednym z podstawowych problemów współczesnej kanonistyki. Zarówno poprzedni jak i obowiązujący Kodeks Prawa Kanonicznego (dalej: KPK/83) nie podają takiej definicji. Jej sformułowanie nie należy do ustawodawcy, którego zadaniem jest wydawać przepisy prawne. Skutki aktywności ustawodawczej wpisują się w szereg istniejących aktów normatywnych. Ustawodawca może wydawać również akty normatywne nie będące ustawą. Stąd też istnieje wymóg określenia aktu normatywnego, który nazywa się ustawą i który spełniałby jej warunki.

Podczas prac nad rewizją Kodeksu Prawa Kanonicznego z 1917 r. (dalej: KPK/17) postulowano, co widać w poszczególnych schematach nowego KPK, włączenie do niego definicji ustawy. Ostatecznie jednak zwyciężyła opcja przeciwna, która stała na stanowisku, że definiowanie pojęć jest zadaniem doktryny, a nie ustawodawcy. 
Istnieje przekonanie, że umieszczanie definicji ogólnych w tekstach normatywnych może skutkować brakiem pewności prawa, ze względu na niemożliwość ich konsekwentnego przestrzegania ${ }^{1}$. Ponadto podnoszono kwestię, że dotychczas powszechnie akceptowana definicja ustawy św. Tomasza z Akwinu jest zbyt szeroka i obejmuje również inne formy aktów normatywnych, jak choćby nakazy².

Do braku odniesienia w tekście normatywnym do definicji ustawy przyczyniła się również ówczesna doktryna kanonistyczna. Sprowokowała do nowej dyskusji na temat ustawy kanonicznej. Podczas III Międzynarodowego Kongresu Prawa Kanonicznego w Pampelunie w 1976 r., którego tematem była norma kanoniczna (Norma in iure canonico) E. Corecco wyszedł z propozycją zdefiniowania na nowo ustawy kanonicznej. Najważniejszym elementem, który poddał krytyce było określenie ustawy kanonicznej jako ordinatio rationis. Uważał, że takie jej określenie wskazuje na jej monistyczny charakter. Nie jest również adekwatne do całości prawa kościelnego, w którym nie rozum, lecz wiara jest ostatecznym kryterium określającym treść norm prawnych ${ }^{3}$. Tym samym dał on początek dyskusji, która dotyczy charakteru rozporządzenia (ordinatio) i jednocześnie zainicjował nowe próby zdefiniowania ustawy kanonicznej. Nie oznacza to jednak, że rola rozumu została całkowicie wyeliminowana, wszak fides querit intellectum. W definicji ustawy kanonicznej nie chodzi bowiem jedynie o zastąpienie określenia ordinatio rationis określeniem ordinatio fidei. Główną rolę odgrywa określenie ordinatio, czyli sposób w jaki wiara nakazuje rozumowi. W ten sposób otwiera się przestrzeń dla szerszego zagadnienia jakim jest zależność pomiędzy wiarą a rozumem w procesie poznania. R. Sobański stwierdził, że problem ten

\footnotetext{
${ }^{1}$ Por. W. Aymans, Rozważania o wewnętrznych cechach istotnych kanonicznego pojęcia ustawy, Śląskie Studia Historyczno-Teologiczne 25/26(1992-93), s. 197.

2 Por. J. García Martín, Le norme generali del Codex Iuris Canonici, Roma 1995, s. 42.

3 Por. R. Sobański, Ustawa kościelna - „ordinatio rationis” czy „ordinatio fidei', Collectanea Theologica 48(1978) 1, s. 27.
} 
nie należy do kanonistów ${ }^{4}$. Naprzeciw tej problematyce wychodzi encyklika Jana Pawła II Fides et ratio, którą czyta również i kanonista.

\section{Za i przeciw Tomaszowej definicji ustawy podczas prac nad rewizją KPK}

W długiej tradycji kanonistycznej przyjmowano definicję ustawy św. Tomasza, którą aplikowano do prawa kanonicznego w jej podstawowym brzmieniu lub próbując dostosowywać ją do społeczności kościelnej. Kanoniści opowiadali się również za definicją ustawy podaną przez F. Suareza. W definicji Tomasza istnieją cztery elementy charakterystyczne dla ustawy. Są to: rozporządzenie rozumu, dobro wspólne, kompetentny dla społeczności ustawodawca oraz promulgacja $^{5}$. Definicja Suareza zawiera również cztery elementy: zarządzenie ogólne, sprawiedliwe, wydane na stałe, wystarczająco promulgowane ${ }^{6}$. Obie definicje różnią się w trzech elementach, które jednak się uzupełniają, dając tym samym możliwość skonstruowania definicji o pełniejszej i bardziej wyczerpującej treści. Tomasz ponadto zaznacza, że wykonawcą rozrządzenia rozumu jest sam ustawodawca. Dla Suareza jest to kwestia otwarta. Elementem wspólnym jest kategoria dobra wspólnego, o ile wymóg sprawiedliwości będzie rozumiany jako szczególny jego wymiar ${ }^{7}$.

Wśród autorów komentujących KPK/17 są tacy, którzy akceptują definicję Tomaszową bez żadnej korekty powodowanej odniesieniem jej do społeczności kościelnej oraz tacy, którzy aplikują ją do tejże społeczności. Do zwolenników pierwszej opcji należą chociażby F. Cappello, który podkreśla równoznaczną treść definicji Tomasza i Suareza uwypuklając jedynie, że rozrządzenie rozumu jest wydane

\footnotetext{
${ }^{4}$ Por. Tamże, s. 31.

${ }^{5}$ Summa Theologica, I-II. q. 90, a. 4: „quaedam rationis ordinatio ad bonum commune, ab eo qui curam comunitatis habet, promulgata".

${ }^{6}$ De legibus ac Deo legislatore, lib I cap. 12 n. 5: „commune praeceptum, iustum ac stabile, sufficienter promulgatum".

${ }^{7}$ Por. W. Aymans, Rozważania o wewnętrznych cechach istotnych kanonicznego pojęcia ustawy, s. 198-199.
} 
na stałe ${ }^{8}$; podobnie pisze M. Conte a Coronata, który przyjmuje zamienne definicję Tomasza i Suareza ${ }^{9}$; A. Vermeersch i J. Creusen, którzy w swoim komentarzu przywołują jedynie definicję Tomaszową bez jakiejkolwiek zmiany ${ }^{10}$ czy w obszarze polskiej kanonistyki F. Bączkowicz, J. Baron, W. Stawinoga działający tak samo jak wyżej wskazani autorzy ${ }^{11}$. Definicję Tomaszową ustawy, uzupełnioną o określenie społeczności (communitas ecclesiastica) dla której została ona wydana, przyjmują np. F. Wernz wraz z P. Vidal ${ }^{12}$, F. Maroto ${ }^{13}$ czy G. Michiels ${ }^{14}$. Wprowadzenie jednak określenia społeczności kościelnej przy zastosowaniu Tomaszowej definicji ustawy nie wskazuje na jej specyfikę w odniesieniu do prawa kanonicznego. Służy ono raczej podkreśleniu roli ustawodawcy kościelnego jako jedynego, który posiada w stosunku do wspólnoty władzę ustawodawczą. Przyjęcie jednej jak i drugiej definicji ustawy podkreśla również jej charakter rozumowego rozrządzenia, gdzie rozum stanowi czynnik porządkujący kościelną społeczność. Drugim charakterystycznym elementem jest jej odniesienie do dobra wspólnego, które jest przyczyną celową istnienia ustaw w Kościele.

Podczas prac nad rewizją KPK/17 redaktorzy pierwszych prowizorycznych schematów (lata: 1968, 1973, 1974 ${ }^{15}$ ) przyszłego prawa kościelnego wybrali dotychczasową opcję, by nie umieszczać w przyszłym kodeksie definicji ustawy kanonicznej. Mogło to być również

\footnotetext{
${ }^{8}$ Por. F. Cappello, Summa Iuris Canonici, t. 1, Romae 1961, s. 57.

${ }^{9}$ Por. M. Conte a Coronata, Institutiones Iuris Canonici ad usum utriusqae cleri et scholarum, t. 1, Torino 1950, s. 14.

10 Por. A. Vermeersch, J. Creusen, Epitome Iuris Canonici, t. 1, Mechliniae-Romae 1927, s. 54.

${ }^{11}$ Por. F. Bączkowicz, J. Baron, W. Stawinoga, Prawo kanoniczne. Podręcznik dla duchowieństwa, t. 1, Opole 1957, s. 184.

12 Por. F. Wernz, P. Vidal, Ius Canonicum ad Codicis normam exactum, t. 1, Romae 1938, s. 153.

${ }^{13}$ Por. F. Mавото, Instituciones de Derecho Canónico en conformidad con el nuevo Código, t. 1, Madrid 1919, s. 189.

14 Por. G. Michiels, Normae generales iuris canonici, t. 1, Parisiis-Tornaci-Romae 1949, s. 154.

15 Por. Communicationes 19 (1987), s. 92; 22 (1990), s. 259; 23(1991), s. 72, 148-149.
} 
spowodowane soborową odnową i nowym, jeszcze przedsoborowym, spojrzeniem na prawo kanoniczne. W ten nurt wpisuje się także krytyka możliwości aplikacji definicji ustawy Tomasza i Suareza podjęta w tym samym czasie przez E. Corecco. W Schemacie nowego kodeksu z 1979 r. $^{16}$, a następnie w Schemacie z $1980 \mathrm{r}^{17}$ znajdujemy definicję ustawy kanonicznej, którą jest definicja ustawy Tomasza. Zostało w niej jednak pominięte odniesienie do rozporządzenia rozumu. Ponadto zarzucano jej, że niezbyt precyzyjnie określa podmiot pasywny ustawy oraz nie wskazuje na charakter trwałości (stabilności) norm ${ }^{18}$.

W odniesieniu do takiej definicji ustawy pojawiły się konkretne zarzuty. Pierwszy z nich dotyczył jej charakteru. Wydawała się zbyt ogólna i dlatego powinna zostać usunięta $\mathrm{z}$ kodeksu. Po drugie: odniesienie do celu jakim jest dobro wspólne wyraża zbyt woluntarystyczne podejście do ustawy, które nie odpowiada duchowi Ewangelii, życiu i historii Kościoła. Trzeci zarzut dotyczył nieprecyzyjności, gdyż definicja nie precyzuje czy chodzi o ustawę. Świadczy o tym przede wszystkim sformułowanie norma... data, które można aplikować także do ustaw partykularnych czy specjalnych, wydawanych przez każdą władzę dla dobra jakiejkolwiek wspólnoty ${ }^{19}$.

Odpowiedź na powyższe zarzuty była następująca. W stosunku do pierwszego zarzutu stwierdzono, że istnieje konieczność zdefiniowania ustawy kanonicznej ze względu na bezpieczeństwo prawne tak, by było jasno określone czy chodzi o ustawę czy inny akt normatywny. Było to spowodowane praktyką Dykasterii Kurii Rzymskiej, które, podczas prac nad rewizją KPK/17, poprzez swoje akty normatywne

\footnotetext{
16 „Lex norma scilicet generalis ad bonum commune alicui communitati a competenti auctoritate data, instituitur cum promulgatur", Communicationes 23(1991), s. 162.

17 Por. Pontificia Commissio Codici Iuris Canonici Recognoscendo, Schema codicicis iuris canonici iuxta animadversiones S.R.E. Cardinalium, Episcoporum Conferentiarum, Dicasteriorum Curiae Romanae, Universitatum Facultatumquae ecclesiasticarum necnon superiorum Institutorum vitae consecratae recognitum (Patribus Commissionis reservatum), Lib. Ed. Vaticana 1980, s. 4.

${ }_{18}$ Por. J. García Martín, Le norme generali del Codex Iuris Canonici, s. 45.

19 Por. Tamże, s. 42-43.
} 
derogowały obowiązujące normy kodeksowe. Na drugi zarzut odpowiedziano, że źródłem obowiązywalności prawa jest dobro wspólne oraz wola samego ustawodawcy. W odniesieniu do trzeciego zarzutu stwierdzono, że każda ustawa posiada charakter ogólności, w tym także partykularna. Słowo generalis w definicji ustawy wskazuje, że odróżnia się ustawę od wszelkich norm wydanych dla poszczególnych osób uti singuli ${ }^{20}$. Po tych wyjaśnieniach tekst definicji ustawy został zawarty w kolejnym schemacie z $1982 \mathrm{r}^{21}$, ale zniknął z kodeksu promulgowanego w $1983 \mathrm{r}$.

Dyskusja wokół definicji ustawy kanonicznej w okresie prac nad rewizją KPK/17 wskazuje, że przedstawiane argumenty dotyczyły nie tylko tego, czy zamieścić ją czy też nie w nowym kodeksie. Punktem spornym w całej dyskusji były raczej elementy zewnętrzne ustawy: jej ogólność i mała precyzja. W dyskusji nie pojawia się problem jej elementów wewnętrznych dotyczących charakteru rozporządzenia ustawodawcy czy jej odniesienia do dobra wspólnego. W przypadku tego ostatniego uwaga koncentrowała się nie na określeniu czym jest dobro wspólne w Kościele, lecz jedynie na akceptacji lub negacji jego roli jako źródła mocy obowiązującej ustaw.

\section{Krytyka aplikacji definicji ustawy Tomasza do prawa kanonicznego}

Wywody św. Tomasza dotyczące definicji ustawy należy dostrzegać na tle jego teologii rzeczywistości, w której Bóg jest przyczyną sprawczą wszystkich rzeczy i którymi kieruje według swego planu (lex aeterna) ku ostatecznemu celowi. Człowiek poznaje lex aeterna, gdyż jej odbicie znajduje się w ludzkiej naturze. Uczestniczy w niej

\footnotetext{
20 Pontificia Commissio Codici Iuris Canonici Recognoscendo, Relatio complectens synthesim animadversionum ab Em.mis atqae Ex.mis Patribus Commisionis ad novissimum schema codicis iuris canonici exhibitarum, cum responsibus a secretaria et consultoribus datis (Patribus Commissionis stricte reservata), Typ. Pol. Vaticanis 1982, s. 21-22.

${ }^{21}$ Pontificia Commissio Codici Iuris Canonici Recognoscendo, Codex iuris canonici schema novissimum iuxta placita Patrum Commissionis emandatum atquae Summo Pontifici praesentatum, Typ. Pol. Vaticanis 1982, can. 7.
} 
poprzez prawo naturalne (lex naturalis). Prawo naturalne jest uczestnictwem rozumnego stworzenia w prawie odwiecznym. Skoro rozum ludzki uczestniczy w rozumie boskim to poznanie boskiego planu stworzenia nie może być arbitralne. Dla Tomasza rozum ludzki jest narzędziem poznania oraz konkretyzowania prawa. Na tej podstawie podaje definicję ustawy, którą odnosi do lex aeterna, naturalis, humana i również divina. W odniesieniu jednak do lex aeterna i divina wypracowana wspólna (nie ogólna, metafizyczna ${ }^{22}$ ) definicja ustawy może być aplikowana jedynie w sposób analogiczny, co wynika ze scholastycznych przekonań dotyczących podporządkowania rozumu wierze i filozofii teologii ${ }^{23}$. Niezależnie od porządku naturalnego wraz z podporządkowaniem praw (lex aeterna, naturalis, humana) Tomasz wskazuje na istnienie porządku nadprzyrodzonego, opartego na sekwencji lex aeterna, divina, canonica (ecclesiatica) zachowując ideę jedności prawa poprzez odniesienie wszystkich do lex aeterna. Zarówno prawo ludzkie (świeckie) jak i kościelne mają swoje odniesienie ostateczne do prawa wiecznego, z którego wynikają jako z zasad znanych rozumowi $z$ natury lub wiary na zasadzie konkluzji czy konkretyzacji. Dwa niezależne porządki dopełniają się realizując cel planu, którego przyczyną sprawczą jest sam Bóg. Z tego powodu nie ma w twórczości Tomasza odrębnej definicji ustawy kanonicznej, gdyż także i ona jest rozporządzeniem rozumu, wydanym przez kościelnego przełożonego dla wspólnego dobra Kościoła ${ }^{24}$.

Do takiego pojmowania prawa (w tym ustawy) przyczyniły się również warunki zewnętrze. Czasy św. Tomasza to jedna christianitas, w której porządek kanoniczny przeplata się z porządkiem prawnym świeckim, prałaci wraz z książętami stanowili prawo dla jednej społeczności. Cała christianitas była podporządkowana

\footnotetext{
22 Por. F. X. Urrutia, Les normes générales, Paris 1994, s. 29.

${ }^{23}$ Por. E. Conecco, «Ordinatio rationis» o «ordinatio fidei»? Appunti sulla definizione della legge canonica, w: Tenże, Ius et Communio. Scritti di Diritto Canonico, Casale Monferato - Lugano 1997, s. 146.

${ }^{24}$ Por. L. Gerosa, Teologia del diritto canonico: fondamenti storici e sviluppi sistematici, Lugano - Varese 2005, s. 51-55.
} 
prawu wiecznemu. Rozum ludzki w procesie stanowienia prawa nie był osamotniony. Był rozumem oświeconym wiarą. Rozum i wiara tworzyły jedność. Problem, który się pojawił nie dotyczył konfliktu między rozumem a wiarą, lecz między rozumem a wolą w procesie stanowienia prawa.

Dodatkowo był to okres, w którym mocno odbijały się echa reformy gregoriańskiej oraz dążenie do centralizacji władzy, zarówno papieskiej jaki i świeckiej, oraz dostrzegania prawa jako narzędzia kierowania życiem społecznym. Przejście od społeczeństwa stanowego do państwa opartego na centralizacji władzy przyczyniło się do tego, że prawo znalazło się w gestii władcy, który stał się jedynym odpowiedzialnym za jego stanowienie. „Od XII w. nazwie lex przypisuje się techniczne znaczenie aktu ustawodawczego" ${ }^{25}$. Jednocześnie zmieniła się rola prawa cywilnego, które stało się prawem państwowym, a lex canonica przestała mieć znaczenie prawa powszechnego, wiążąc już tylko samych katolików.

W tradycji kanonistycznej przez wiele wieków przyjmowano definicję ustawy Tomasza. Było to w dużej mierze spowodowane koniecznością obrony własnego prawa kościelnego. Należało zatem ukazać jego prawomocność na tej samej zasadzie na jakiej istnieje ono w państwie, gdyż obie społeczności jako doskonałe mają prawo do własnego prawa. Wiązała się z tym konieczność coraz większej racjonalizacji prawa (logiczność, klarowność, pewność, jednolitość), które całkowicie zostało sprowadzone do ustaw. W znacznej mierze prawo państwowe $\mathrm{w}$ jego formalnej i zewnętrznej formie stało się wzorem dla prawa kościelnego.

W 1976 r. po raz pierwszy w środowisku katolickim ${ }^{26}$ został poddany pod dyskusję zasadniczy element Tomaszowej definicji jakim

\footnotetext{
${ }^{25}$ R. Sobański, Dobro wspólne w definicji ustawy św. Tomasza z Akwinu, w: I. Bogucka, Z. Tobor, Prawo a wartości. Księga jubileuszowa Profesora Józefa Nowackiego, Zakamycze 2003, s. 253.

${ }^{26}$ Por. L. Gerosa, Interpretacja prawa w Kościele. Zasady, Wzorce, Perspektywy, Kraków 2003, s. 63.
} 
jest rozporządzenie rozumu. E. Corecco ${ }^{27}$ zauważył, że od czasów Kartezjusza zmianie uległo ujmowanie roli rozumu. Tym samym nastąpiło przejście od kulturowego panowania chrześcijaństwa do kulturowego panowania nowoczesności. Nowa epoka charakteryzuje się tym, że rozum staje się jedyną jednostką miary całej rzeczywistości, całkowicie uniezależnia się od wiary. Jako norma universi przeciwstawia się wierze. Znaczące przejście w pojmowaniu roli rozumu miało również swoje konsekwencje dla nauk prawnych. Rozum przestał być narzędziem, za pomocą którego poznaje się prawo odwieczne obecne w ludzkiej naturze. Stał się jedynym źródłem prawa ${ }^{28}$. Zmiana roli rozumu nie pozwala zatem na zastosowanie do definicji ustawy kanonicznej kategorii ordinatio rationis ze względu na to, iż prawo kanoniczne znajduje w prawie Bożym swoje koniecznościowe odniesienie. Prawo kanoniczne znajduje w nim swoje potwierdzenie i kryterium. Pojęcie rozumu nie może mieć tego znaczenia, które miało w definicji Tomasza ${ }^{29}$.

E. Corecco twierdzi zatem, że w odniesieniu do ustawy kanonicznej rolę rozrządzająca pełni nie rozum, lecz wiara (ordinatio fidei). Jego argumentacja brzmi następująco: 1. Prawo wieczne ujęte $\mathrm{w}$ aspekcie filozoficznym znajduje w prawie pozytywnym jako ordinatio rationis swój odpowiednik. Natomiast prawo wieczne jako Boże prawo pozytywne (z punktu widzenia teologicznego) nie znajduje swojego odniesienia $w$ rozumie lecz $w$ sposobie poznania opartym na wierze. 2. Wiara poznaje przyjmując autorytet „słowa-świadectwa” Boga, tzn. łaski. Rozum natomiast opiera się na motywacji, którą jest dowodząca siła właściwa dla ratio. Motywacją poznania przez wiarę nie jest zatem ludzka logika, lecz ratio divina. Jako racja i przyczyna wszystkich rzeczy wyraża się na zewnątrz poprzez ordinatio, autorytet

${ }^{27}$ Por. E. Corecco, Valore dell'atto "contra legem", w: La norma en el Drecho Canónico. Actas del III Congreso Internacional de Derecho Canónico, Pamplona, 10-15 octubre de 1976, t. 1, Pamplona 1979, s. 839-859.

${ }^{28}$ Przykładem takiego podejścia jest racjonalistyczna szkoła prawa natury począwszy od. H. Grocjusza.

${ }^{29}$ Por. L. Gerosa, Interpretacja prawa w Kościele. Zasady, Wzorce, Perspektywy, s. 64 . 
samego Boga, w której człowiek uczestniczy poprzez łaskę zawartą w wierze. 3. Na mocy autorytetu Boga człowiek przyjmuje jego słowo jako zobowiązujące. Dlatego też nie można uważać ustawy jako ordinatio rationis, lecz jako ordinatio fidei. Prawo kanoniczne nie jest zatem kategorią rozumu, lecz nakazem wiary ${ }^{30}$.

Kontekstem długotrwałej obecności definicji ustawy Tomasza na polu prawa kanonicznego była z pewnością kategoria społeczności doskonałej akceptowana i odnoszona do Kościoła, który jest wyniesiony do godności nadprzyrodzonej. Kościół nie jest jednak, ze względu na swój cel, społecznością naturalną wyniesioną do tejże godności. W takiej sytuacji byłby jedynie społecznością (stowarzyszeniem religijnym jak twierdził S. Puffendorf), której zadaniem byłoby zaspokojenie religijnych potrzeb człowieka. Tą drogą nie da się poznać i zrozumieć rzeczywistości Kościoła.

Kościól jest przedmiotem poznania teologicznego opartego na wierze. Jest fenomenem wiary, gdyż nie istnieje z naturalnej konieczności, lecz z woli Chrystusa jako „znak i narzędzie zbawienia”. Wszystko, co w Kościele istnieje jest elementem dokonującego się w nim i poprzez niego zbawczego dzieła Chrystusa. Uczestniczy w nim własne prawo Kościoła, zakorzenione w jego strukturze. Nie może być zatem pojmowane poza tą charakterystyczną i odróżniającą go od prawa państwowego charakterystyką. Nie jest również produktem rozumu, lecz wiary. W. Aymans ujmuje tę prawdę w znaczącym sformułowaniu: „Ani podstawowych struktur ustroju kościelnego, ani podstawowych sposobów kościelnego życia w Słowie i sakramencie nie można wyprowadzić z jakiegokolwiek rozumu; wynikają one wyłącznie z historycznego rozumienia Objawienia. I w tym znaczeniu można prawo kościelne rozumieć jedynie jako „ordinatio revelationis” lub w tym sensie jako „ordinatio fidei” ${ }^{31}$.

\footnotetext{
${ }^{30}$ Por. E. Conecco, «Ordinatio rationis» o «ordinatio fidei»? Appunti sulla definizione della legge canonica, s. 152-156.

${ }^{31}$ W. Aymans, Rozważania o wewnętrznych cechach istotnych kanonicznego pojęcia ustawy, s. 199.
} 


\section{Obecne definicje ustawy kanonicznej}

Analiza wielu komentarzy i napisanych opracowań dotyczących ustawy kanonicznej pozwala na stwierdzenie, że w przeważającej liczbie nie znajdujemy w nich jej definicji. Doktryna kanonistyczna, zbudzona i poruszona przez E. Corecco, nie wypracowała jednej, powszechnie akceptowanej definicji. Istnieją opracowania, które przedstawiają i pogłębiają definicję zaproponowaną przez E. Corecco ${ }^{32}$. Niektórzy autorzy i komentatorzy proponują definicję ustawy kanonicznej, bazując głównie na tych jej elementach, które można odnaleźć w KPK. W większości przypadków koncentrują się jedynie na wskazaniu koniecznych elementów ustawy kanonicznej, które wyróżniają ją od innych aktów normatywnych (prawnie zobowiązujący charakter, rozumność, kompetentny prawodawca, wspólnota zdolna do przyjęcia prawa, generalność, abstrakcyjność, stałość, promulgacja ${ }^{33}$ ).

Spośród nielicznych prób definiowania ustawy kanonicznej, które posiadają charakter prywatnych ekspozycji, przedstawię kilka tytułem egzemplifikacji.

P. Lombardía definiuje ustawę w następujący sposób: akt władzy ustawodawczej Kościoła, o charakterze generalności, w którym sposób postępowania wyrażony jest w odpowiedniej formie, ustalonej poprzez promulgację ${ }^{34}$.

V. De Paolis i A. Montan podają następującą definicję: akt, poprzez który kompetentny prawodawca kościelny wydaje wspólne dyspozycje, zawarte w promulgowanych formach dla wspólnoty zdolnej do przyjęcia prawa $^{35}$.

\footnotetext{
${ }^{32}$ Por. cytowane artykuły R. Sobańskiego, W. Aymansa. Także L. GerosA, La legge canonica quale "ordinatio fidei». La lezione di Eugenio Corecco sul metodo scientifico nella canonistica, w: Tenże (red.), Antropologia, fede e diritto ecclesiale, Milano 1995, s. 15-31.

${ }^{33}$ Tak np. R. SobAŃski, Nauki podstawowe prawa kanonicznego, t. 1, Teoria prawa kanonicznego, Warszawa 2001, s. 52.

${ }^{34}$ Por. P. Lombardía, Lezioni di diritto canonico. Introduzione-Diritto Costituzionale-Parte Generale, Milano 1985, s. 202-203.

${ }^{35}$ Por. V. De Paolis, A. Montan, Il Libro primo del Codice: Norme generali (cann. 1-203), w: Il diritto nel mistero della Chiesa. Il Libro I del codice: le norme generali, Roma 1986, s. 244.
} 
W ujęciu G. Ghirlandy definicja ta brzmi następująco: rozumny nakaz, oświecony wiarą i ukształtowany miłością Ducha Świętego, promulgowany przez kompetentną władzę ${ }^{36}$.

F. X. Urrutia podaje taką definicję: norma ogólna, autonomiczna, promulgowana na mocy władzy episkopalnej, zwłaszcza przez tego, kto jest następcą św. Piotra dla kierowania kościelną wspólnotą publiczną, powszechną lub nie, celem osiągnięcia specyficznych celów Kościoła $^{37}$.

Według W. Aymansa ustawa kościelna jest : „powszechnie, prawnie wiążącym nakazem wiary zmierzającym do wspierania życia „communio" i kształtowanym za pomocą środków rozumu, wydanym i odpowiednio promulgowanym przez kompetentną władzę dla określonego kręgu osób"38.

Dla T. Pawluka ustawa kościelna to: „obowiązująca, rozumna i stała norma postępowania mająca na celu dobro wspólne społeczności, należycie ogłoszona przez właściwego przełożonego"39.

W przytoczonych definicjach ustawy na uwagę zasługuje fakt, że większość z autorów pomija odniesienie ustawy do rozrządzenia rozumu lub wiary. W dużej mierze wynika to ze stanu obecnej wiedzy dotyczącej rozumienia prawa kanonicznego i jego eklezjalnego zakorzenienia. $\mathrm{Z}$ drugiej jednak strony może dziwić fakt, że pomijają jej odniesienie do ordinatio fidei, a bardziej skupiają się na zewnętrznych cechach ustawy niż na jej wewnętrznych wymogach. Próbując usprawiedliwić taką postawę należy podkreślić, że ustawa jest jedynie formą aktu normatywnego, składającą się z odpowiednich przepisów prawnych, $\mathrm{w}$ których zakodowane są normy postępowania. To normy postępowania mają swoje źródło w wierze i wyrażają się

\footnotetext{
${ }^{36}$ Por. G. Ghirlanda, Introduzione al Diritto ecclesiale, Casale Monferato 1993, s. 42 .

37 Por. F. X. Urrutia, Les normes générales, s. 30; Por. także: Tenże, De natura legis ecclesiasticae, Monitor Ecclesiasticus 100(1975), s. 400-419.

${ }_{38}$ W. Aymans, Rozważania o wewnętrznych cechach istotnych kanonicznego pojęcia ustawy, s. 204.

39 T. PAwluk, Prawo kanoniczne według Kodeksu Jana Pawła II, t. 1, Zagadnienia wstępne i normy ogólne, Olsztyn 1985, s. 214.
} 
we wspólnocie Kościoła lub w stosunku do tych, którzy nie są jego członkami. Ustawa jest aktem, a norma regułą zachowania wynikającą z wiary.

G. Ghirlanda wyraża przeświadczenie, że ustawa kościelna jest rozumnym nakazem oświeconym wiarą. Taka koncepcja nie wydaje się słuszna. W ostateczności prawo kościelne byłoby nadal produktem rozumu, a Kościół fenomenem naturalnym, do którego należałoby aplikować postulaty Objawienia. Takie postulaty ze strony Kościoła odnoszą się do wszelkich rzeczywistości ziemskich, w tym samego prawa, i ich rozumowego poznania. Wiara jest dopełnieniem rozumowego poznania. W odniesieniu do prawa oznacza to, że chrześcijański sposób ujmowania doczesności otwiera prawo na jego dopełnienie w kategoriach coraz większej sprawiedliwości i dobra wspólnego oraz wskazuje na osobę nie tylko jako anonimowy podmiot prawa, lecz w pełni jego osobowości ${ }^{40}$. Jest to również głównym zadaniem teologii prawa.

Jako jedyny spośród cytowanych autorów W. Aymans uważa ustawę kanoniczną jako prawnie wiążący przekaz wiary. W innym swoim artykule poświęconym ustawie kanonicznej używa sformułowania ordinatio fide $i^{41}$. Oba sformułowania się uzupełniają i jedno przez drugie jest wyjaśniane. Ordinatio fidei jest przez Aymansa rozumiane jako prawnie wiążący przekaz wiary. Preferuje używanie w miejsce sformułowań «norma» $\mathrm{i}$ «zarządzenie» pojęcia «przekaz» uzasadniając to w następujący sposób: „ludzkie prawo kościelne w swym konkretnym kształcie nie wynika bezpośrednio z wiary, lecz wiara je uzasadnia i wyznacza mu kierunek, a także dlatego, że nawet treści prawa Bożego podlegają rozwojowi historycznemu. Pojęcie «przekaz» nie wyraża przeto złagodzonej mocy wiążącej, lecz dynamiczny charakter ukierunkowanej możliwości rozwoju"².

\footnotetext{
40 Por. T. GaŁkowski, Od człowieka, osoby, podmiotu do podmiotu prawa, Roczniki Nauk Prawnych KUL 18(2008) nr 2, s. 7-41.

${ }^{41}$ W. Aymans, Lex canonica. Considerazioni sulla nozione canonica di legge, s. 112.

42 TenżE, Rozważania o wewnętrznych cechach istotnych kanonicznego pojęcia ustawy, s. 199-200.
} 


\section{Ordinatio rationis w definicji ustawy Tomasza}

Elementy swojej definicji ustawy św. Tomasz zaczerpnął w części od św. Izydora ${ }^{43}$ (cel, jakim jest dobro wspólne) i Gracjana ${ }^{44}$ (promulgacja). Ordinatio rationis, jak twierdzą znawcy tematyki, jest oryginalnym pomysłem Tomasza ${ }^{45}$. W pierwszym artykule Sumy Teologicznej poświęconym zagadnieniu ustawy stwierdza: „Ad hoc ut (voluntas) legis rationem habeat oportet quod sit aliqua ratione regulata: et hoc modo intelligitur quod voluntas principi legis habet vigorem, alioquin voluntas Principis magis esset iniquitas quam lex" ${ }^{36}$. Tym samym wskazuje, że ustawa (lex) zawiera w sobie jakieś rozrządzenie rozumu, czym wyraża przekonanie wcześniej wyrażone przez Ulpiana ${ }^{47}$.

Cechą charakterystyczną ordinatio rationis jest ukierunkowanie na dobro wspólne, które stanowi przyczynę celową rozrządzenia. Dobro wspólne różni się od dobra jednostkowego. Dobro wspólne charakterystyczne dla ustawy odnosi się bowiem do wypełnienia sprawiedliwości. Prawo zmierza do realizacji dobra wspólnego, zgodnie z Bożą sprawiedliwością. W ten sposób czyni ludzi dobrymi. Jeśli prawo nie dąży do tego, co jest dla nich dobre, ale do tego, co jest jedynie korzystne lub przyjemne („utile delectabile sibi”) i niezgodne z Bożą sprawiedliwością („ordinatio non secundum iustitiam”) czyni ludzi dobrymi jedynie względem panującego reżymu ${ }^{48}$. Takie rozrządzenie nie może nazywać się lex.

Połączenie rozrządzenia ze sprawiedliwością wskazuje na drugą jego cechę. Tomasz podkreśla, że pierwszą regułą dla rozumowego

\footnotetext{
${ }^{43}$ Izydor, Etymologiae 5, 21: „Nullo privato commodo, sed pro communi civium utilitate conscripta".

${ }^{44}$ D.1 c.4,3:„Lex instituitur cum promulgatur”.

${ }^{45}$ Por. O. Lottin, La définition classique de la loi, Revue Néoscolastique de philosophie, 27(1925) 6, s. 132.

${ }^{46}$ S. Th., I-II, q. 90, a. 1.

${ }^{47}$ Por. O. RobledA, La noción de la ley en relación con la ideas romanas, Gregorianum 58(1967) 2, s. 285.

${ }^{48}$ Por. S.Th., I-II, q. 92, a. 1.
} 
rozrządzenia jest jego koniecznościowe odniesienie do lex naturalis: „rationis autem prima regula est lex naturae" ${ }^{\text {"9 }}$.

Z powyższych dwóch cech wynika, że rozrządzenie rozumu, które stoi u podstaw ustawy nie jest jakimkolwiek swobodnym rozrządzeniem, lecz takim, w którym należy brać pod uwagę naturalną i Bożą sprawiedliwość. Ich poznanie znajduje się w możliwościach rozumowych człowieka, gdyż poznanie Bożej sprawiedliwości wyraża się na zewnątrz i uobecnia w prawie naturalnym. Wobec tego, Tomasz uważa, że każdy akt woli ustawodawcy, który nie spełnia kategorii sprawiedliwości i nie jest ukierunkowany na realizację dobra wspólnego jest tylko „perversitas legis”50. O takim prawie można powiedzieć, że stanowi ono wyraz woli władcy (imperium, dictamen voluntatis) gdyż nie jest secundum iustitiam. Dla Tomasza ustawa jest konsekwencją ścisłej jedności pomiędzy rozumem i wolą.

W zagadnieniu $91 \mathrm{w}$ art. 4-5 Tomasz rozważa kwestie dotyczące porządku nadprzyrodzonego i konieczności Bożego prawa pozytywnego. Uważa, że jest ono konieczne gdyż prawo wiedzie człowieka ku realizacji celu ostatecznego, którym jest sam Bóg. Gdyby cel życia ludzkiego nie wykraczał poza współmierność naturalnych uzdolnień człowieka nie potrzebowałby on kierownictwa prawa wyższego od przyrodzonego czy ludzkiego. Konieczność prawa Bożego wynika również z niepewności ludzkich ocen i odmienności zdań co do ludzkiego postępowania, w oparciu o błędne poznanie prawa naturalnego, następstwem czego jest stanowienie różnych i przeciwnych sobie praw. Prawo Boże pozytywne wychodzi naprzeciw ludzkim wątpliwościom, zapewniając pewność ludzkiemu postępowaniu w tym, co należy czynić i czego unikaćs1.

Prawo Boże Tomasz dzieli na prawo stare i nowe, które w sposób odmienny realizują w sobie trzy istotne cechy prawa: 1) prawo stare prowadzi do dobra wspólnego jako celu ziemskiego, nowe zaś do niebieskiego i duchowego; 2) prawo stare kieruje ludzkim postępowaniem

\footnotetext{
${ }^{49}$ S. Th., I-II, q. 95, a. 2.

${ }^{50}$ S. Th., I-II, q. 92, a. 1.

${ }^{51}$ Por. S. Th., I-II, q. 91, a. 4.
} 
według porządku sprawiedliwości, nowe zaś także w wewnętrznych uczynkach duszy; 3) stare prawo prowadzi ludzi do przestrzegania przykazań pod groźbą kar, nowe nakazuje ich zachowanie z cnoty miłości, wlanej w serca dzięki łasce Bożej ${ }^{52}$.

Tomasz stwierdza, że poznanie nowego prawa dokonuje się inaczej niż poznanie lex aeterna. W tej człowiek uczestniczy mocą swoich rozumowych możliwości poznawczych. Lex divina można poznać jedynie dzięki łasce Bożej wlanej w ludzkie serca. Nie jest to więc poznanie oparte na samym rozumie. Wynika to z celu, ku któremu prowadzi prawo Boże. Jest nim osiągnięcie szczęśliwości wiecznej, która wykracza poza współmierność naturalnych uzdolnień człowieka ${ }^{53}$. Poznanie przez wiarę jest wyższym i pełniejszym sposobem uczestnictwa w lex aeterna.

Tomasz odróżniając wyraźnie porządek naturalny od nadprzyrodzonego wskazuje na ich jedność wokół idei prawa wiecznego ${ }^{54}$. W tym pierwszym istnieje możliwość poznania prawdy i prawa naturalnego w oparciu o rozumową aktywność człowieka. W przypadku prawa Bożego pozytywnego poznanie prawdy i prawa dokonuje się dzięki łasce. Tomasz wyraźnie stwierdza w zagadnieniu 109, że umysł ludzki jest wyposażony w światło umysłowe, dzięki któremu poznaje te przedmioty, które są poznawalne przy pomocy zmysłów. Do poznania przedmiotów wyższego rzędu potrzebuje światła wiary, światła łaski. Potrzebuje mocy Bożej, tego, by Bóg pobudził umysł człowieka do działania ${ }^{55}$.

Rozważania Tomasza dotyczące konieczności światła wiary i łaski celem poznania rzeczywistości Bożej, w tym pozytywnego prawa Bożego wskazują, że można by na interpretację Tomaszowej definicji

\footnotetext{
${ }^{52}$ S. Th., I-II, q. 91, a. 5.

${ }^{53}$ Por. S. Th., I-II, q. 91, a. 4.

${ }^{54}$ Lex aeterna nie stanowi analogatum maius dla lex naturalis i dla lex humana, gdyż zawiera w sobie również porządek zbawienia. Nie może być poznawana jedynie za pomocą analogi bytu (analogia entis), lecz również w sposób całkiem różny na drodze analogii wiary (analogia fidei). Por. E. CoRecco, «Ordinatio rationis» o «ordinatio fidei»? Appunti sulla definizione della legge canonica, s. 149.

${ }^{55}$ Por. S. Th., I-II, q. 109, a. 1.
} 
ustawy spojrzeć z innego punktu widzenia biorąc pod uwagę, że prawo kanoniczne ma swoje koniecznościowe odniesienie do Bożej sprawiedliwości (prawa Bożego). Jego zadaniem jest przekazywanie i wyjaśnianie historycznie prawa Bożego.

Nie do końca jest to jednak możliwe, co wynika z przekonań Tomasza dotyczących związku pomiędzy nowym prawem Bożym a prawem kanonicznym. Tomasz nie zajmował się w swojej Sumie prawem kanonicznym. Tym samym nie poruszał problemu ustawy kanonicznej samej w sobie. Punktem wyjścia definicji ustawy były modele prawne tradycji rzymsko - chrześcijańskiej, w której przyszło Tomaszowi żyć. Dla niego ratio była najwyższą zasadą ludzkich aktów, w przeciwieństwie do franciszkańskiego (Bonawentura) sakralno - woluntarystycznego podejścia średniowiecznych nominalistów. Dzięki niej człowiek jest w stanie poznać Boga na drodze filozoficznego dyskursu ale też zrozumieć zgodność i racjonalną niesprzeczność danych Objawienia. Definicję ustawy aplikował zatem analogicznie do wszystkich jej rodzajów (lex aeterna, naturalis, divina, humana, canonica) ${ }^{56}$.

Rozważania Tomasza dotyczyły prawa Bożego (stare i nowe) oraz w świetle jego dyspozycji zakresu działalności prawodawczej. Prawo kanoniczne traktował na podobieństwo prawa stanowionego przez człowieka w ich wspólnym odniesieniu do prawa wiecznego: prawo ludzkie poprzez prawo naturalne, a prawo kanoniczne poprzez prawo Boże. Wydaje się jednak, że związek zależności pomiędzy prawem kanonicznym a Bożym nie jest tak ścisły jak pomiędzy prawem ludzkim a naturalnym. Wynika to przede wszystkim z rozważań Tomasza dotyczących nowego prawa (lex nova), które znajduje się w relacji raczej do sfery mistycznej Kościoła jako duchowej wspólnoty pomiędzy Chrystusem i wierzącymi. W mniejszym stopniu lex

\footnotetext{
${ }^{56}$ Tomasz nie sprowadza wiary do rozumu jak i teologii do filozofii, stąd lex aeterna i lex canonica nie mogą w sposób jednoznaczny przyjmować ogólnej, metafizycznej definicji ustawy, lecz jedynie w sposób analogiczny o czym świadczą cztery elementy jego definicji. Por. E. Conecco, «Ordinatio rationis» o «ordinatio fidei»? Appunti sulla definizione della legge canonica, s. 146.
} 
nova odnosi się do instytucjonalnego wymiaru Kościoła widzialnego. Wydaje się, jak analizuje E. Corecco ${ }^{57}$, że Tomasz czyni dużą cezurę pomiędzy prawem kanonicznym a pozytywnym prawem Bożym. Potwierdzeniem tej tezy jest traktowanie ustawodawcy świeckiego na tym samym poziomie co kościelnego. Obaj pozostają całkowicie wolni w stanowieniu prawa mając na względzie czy to prawo naturalne czy Boże ${ }^{58}$. Swoboda ustawodawcy kościelnego wynika $z$ tego, że może on stanowić prawa jedynie takie, które dotyczą przepisów obrzędowych (liturgia) i sądowych. Wydane w tym zakresie normy nie są jednak konieczne do uzyskania wewnętrznej łaski, aczkolwiek ich przestrzeganie temu służy. Pozostawione wolnemu osądowi ustawodawcy nie posiadają mocy nowego prawa Bożego. Wszystko bowiem to, co potrzebne jest człowiekowi do zbawienia zawarte zostało w prawie Bożym. Dostęp do łaski dokonuje się jedynie przez Chrystusa, który ustanowił w tym celu sakramenty Pozostałe normy konieczne do przyjęcia łaski i pozwalające na cnotliwe życie należą do przykazań moralnych, znanych także w starym prawie. Wyrazem zaś korzystania z łaski jest chrześcijańska postawa miłości ${ }^{59}$.

W dużej mierze aplikacja definicji ustawy Tomasza na gruncie prawa kanonicznego jako ordinatio rationis przez późniejszych komentatorów, uzależnionych również od konieczności apologetycznego podejścia do prawa kościelnego i bez głębszego wniknięcia w tajemnicę Kościoła, przyczyniła się do utrwalenia przekonania o jej słuszności i przydatności. Podkreśliłbym bardziej wymiar praktyczny (przydatność) niż teoretyczny (słuszność).

Możliwość aplikacji przez Tomasza pojęcia ustawy do ustawy kanonicznej, aczkolwiek tego wyraźnie nie czynił, wynikała z jego rozumienia nowego prawa Bożego w jego relacji głównie do wewnętrznej, duchowej struktury Kościoła, w której wierzący odnajdywał wszelkie konieczne środki pozwalające mu na cnotliwe życie i dostąpienie łaski Bożej, osiągnięcie zbawienia. Prawo kanoniczne dla Tomasza posiadało

\footnotetext{
${ }^{57}$ Por, Tamże, s.150.

${ }^{58}$ Por. S. Th., I-II, q. 108, a. 1.

${ }^{59}$ Por. S. Th., I-II, q. 108, a. 2.
} 
charakter porządkujący współżycie wierzących w Chrystusa w ramach działalności liturgicznej i sądowej. Pomiędzy nim a prawem Bożym nie było tak ścisłej zależności jak pomiędzy prawem naturalnym i prawem stanowionym przez człowieka. To drugie było bowiem prawem na tyle, na ile odzwierciedlało naturalny porządek sprawiedliwości. Prawo kanoniczne pełniło rolę zewnętrznego organizatora form przekazu łaski.

Propozycje nowych definicji ustawy kanonicznej, w której główną rolę odgrywa ordinatio fidei było możliwe dzięki rozwojowi eklezjologii i spojrzeniu na prawo kanoniczne nie w jego funkcji organizacyjno - porządkującej, lecz jako element strukturalny Kościoła, w którym to co Boskie łączy się z tym co ludzkie. Tym samym można było wskazać na ścisły związek tego, co Boskie i tego, co ludzkie w ramach jednego porządku prawa kościelnego. Przezwyciężona została Tomaszowa dychotomia pomiędzy prawem Bożym a kanonicznym. Pojmowanie prawa kanonicznego w funkcji, jaką dostrzegał Tomasz sprzyjało przyjmowaniu definicji ustawy jako ordinatio rationis, zawsze z zachowaniem Bożej sprawiedliwości. Sytuacja ta została utrwalona w ramach publicznego prawa Kościoła, które dążyło coraz bardziej do dorównania zasadom prawa państwowego.

\section{Fides et ratio we wzajemnych relacjach}

Przytaczani powyżej kanoniści Aymans, Corecco, Sobański wyraźnie akcentują, że ustawa kanoniczna jest rozrządzeniem wiary. Nie znaczy to, że całkiem pomijają rolę rozumu w odniesieniu do ustawy kanonicznej, tak jakby była czy mogła być nieracjonalna. Aymans podkreśla mocno jego twórczą rolę. W odróżnieniu od ustawy państwowej nie pełni on roli źródła poznania. Rozum jest źródłem poznania jedynie w takim stopniu, $\mathrm{w}$ jakim przekazuje materialną treść ustawy wskazując drogę do „sprawiedliwego uporządkowania dobra wspólnego"60. W przypadku ustawy kanonicznej źródłem poznania jest Objawienie, do którego człowiek ma dostęp przez wiarę. Prawodawca kościelny tworząc prawo jest zobligowany do zachowania tego,

\footnotetext{
${ }^{60} \mathrm{~W}$. Aymans, Rozważania o wewnętrznych cechach istotnych kanonicznego pojęcia ustawy, s. 200.
} 
co poznaje dzięki wierze. Rozum w ustawie kanonicznej, podobnie jak w ustawie państwowej odpowiedzialny jest natomiast za jej kształtowanie. Jego zadaniem jest historyczne formułowanie i rozwijanie nakazów pochodzących z prawa Bożego, zabezpieczanie ich w ustawach oraz umożliwienie praktycznej realizacji. Ostatecznym kryterium, od którego ustawy kościelne są uzależnione pozostaje zawsze wiara ${ }^{61}$.

E. Corecco akcentując wyraźnie przewagę wiary nad rozumem dostrzega ją nie tylko w odniesieniu do zasad prawa Bożego poznawalnych przez wiarę, lecz również na poziomie ich ucieleśniania poprzez normy prawne w konkretnym kontekście historyczno - społecznym. W tym miejscu pojawia się rola rozumu, który wykorzystując metodę prawną, pozostaje zawsze rozumem oświeconym wiarą. Pomiędzy procesem epistemologicznym poznania normy a praktyczną działalnością zmierzającą do jej konkretyzacji w procesie stanowienia prawa konieczna jest całkowita zgodność. Racją tej zgodności jest jedność, jaka istnieje pomiędzy Kościołem duchowym i jego wymiarem społecznym. Jedność pomiędzy epistemologią i praktyką wokół wiary odróżnia Kościół od jakiegokolwiek innego przedmiotu poznania i odróżnia metodę kanonistyczną od każdej innej metody poznawczej. Rolą rozumu oświeconego wiarą jest zatem konkretyzacja w sytuacji historyczno - społecznej wymogów prawa Bożego poznawanych przez wiarę ${ }^{62}$.

Dla R. Sobańskiego zastąpienie określenia ordinatio rationis przez ordinatio fidei jest jedynie początkiem problematyki związanej $\mathrm{z}$ ustawą kanoniczną. Istotnym elementem jest pojęcie samej ordinatio. Pyta o to, w jaki sposób fides ordinat gdyż dla Tomasza rationis est ordinare. W swoich wywodach podkreśla, że wiara to nie tylko poznane i przyjęte dane objawienia (fides qua), lecz przede wszystkim odpowiedź na Boże wezwanie, przylgnięcie do Chrystusa. Wiara jest prawdą i łaską (fides quae), która dostępuje człowieka w Kościele i poprzez Kościół. Nie jest ona jedynie pouczeniem, lecz przede wszystkim rzeczywistością zbawczą, która prowadzi człowieka do uprzedzającej

\footnotetext{
${ }^{61}$ Por. Tamże.

${ }^{62}$ Por. E. Conecco, «Ordinatio rationis» $\mathrm{o}$ «ordinatio fidei»? Appunti sulla definizione della legge canonica, s. 156.
} 
go wspólnoty. Wspólnota posiada charakter zobowiązujący dalszego w niej trwania (jako znaku) i realizowania zbawienia (jako narzędzie). To wszystko, co uczestniczy w przekazie wiary i ją kształtuje posiada moc zobowiązującą, charakter normatywny dla tych, którzy otrzymali łaskę wiary. Charakter wiążący życia chrześcijańskiego nie wynika zatem $\mathrm{z}$ jego ujęcia w normy prawne, lecz ze względu na wiążący charakter wiary, której życie chrześcijańskie jest przekaźnikiem. Ta kościelna realizacja wiary jest punktem wyjścia dla ujmujących ją norm prawnych. Tu pojawia się zadanie dla rozumu. Jego rolą jest: 1) odczytanie wiary przez życie (rozum jako osobowy czynnik akceptacji wiary); 2) zastosowanie technik opisu tej wiążącej formy życia. Rozum jest środkiem przekazu tego, co wiara rozporządziła ${ }^{63}$.

Kwestia wzajemnych relacji pomiędzy rozumem i religią (wiarą) pojawiła się na długo przed nastaniem chrześcijaństwa, kiedy pytano o genezę wszechświata czy istniejących bóstw. Pierwsi twórcy filozofii sięgali poza partykularne tradycje dążąc ku uniwersalnym zasadom i chcąc "dać racjonalną podstawę swoim wierzeniom w boskość" ${ }^{\prime}$. Relacje pomiędzy wiarą a rozumem nabrały charakteru rozważań rozumu powszechnego. Ten ostatni oczyścił się z zewnętrznych więzów partykularnych mitów i otworzył się na transcendencję. Rozum „prawidłowo uformowany był zatem w stanie wznieść się na wyższe poziomy refleksji, tworząc solidny fundament dla pojmowania bytu, rzeczywistości transcendentnej i absolutu" ${ }^{\prime 65}$.

Spotkanie myśli chrześcijańskiej z filozofią starożytną, aczkolwiek nie bez dozy ostrożności z powodu gnostyczno-ezoterycznego podejścia do wiedzy, sprawiło, że myśl chrześcijańska wszczepiła w rozum otwarty na absolut „bogactwo zaczerpnięte z Objawienia... Rozum przekroczył nawet cel, ku któremu nieświadomie dążył mocą własnej natury, i zdołał odnaleźć najwyższe dobro i najwyższą prawdę w osobie

\footnotetext{
${ }^{63}$ Por R. Sobański, Ustawa kościelna - „ordinatio rationis” czy „ordinatio fidei”, s. $32-34$.

${ }^{64}$ Jan PaweŁ II, Fides et ratio (dalej: FR), 36, w: Encykliki Ojca Świętego Jana Pawła II, Kraków 2006.

${ }^{65} \mathrm{FR}, 41$.
} 
Wcielonego Słowa" ${ }^{66}$. Zasługą Ojców Kościoła na gruncie spotkania się wiary chrześcijańskiej ze starożytną filozofią było to, że zdołali „ukazać w pełnym świetle to, co zawarte było tylko pośrednio i we wstępnym zarysie w myśli wielkich filozofów starożytnych" ${ }^{67}$. Ukazanie relacji pomiędzy rozumem i wiarą $w$ myśli średniowiecznej zawdzięczamy głównie Anzelmowi z Cantenbury i Tomaszowi z Akwinu. Anzelm podkreślając pierwszeństwo wiary nie deprecjonuje niezależnych poszukiwań rozumu. Jego zadaniem nie jest jednak „wydawanie opinii o treściach wiary... rola polega na poszukiwaniu sensu, na odkrywaniu rozumnych uzasadnień, które pozwolą wszystkim uzyskać pewne zrozumienie treści wiary" ${ }^{68}$. Pełną harmonię pomiędzy rozumem i wiarą ukazał św. Tomasz. Jej źródłem jest wspólne pochodzenie od Boga. Dlatego, uważa Tomasza, wiara nie lęka się rozumu, pokłada w nim ufność, opiera się na nim i go doskonali. Wartością wiary jest nie tylko jej nadprzyrodzony charakter, lecz również rozumność. Wiara, podkreśla papież przytaczając myśl Tomasza, jest „w pewien sposób «czynnością myśli»; ludzki rozum nie musi zaprzeczyć samemu sobie ani się upokorzyć, aby przyjąć treść wiary; w każdym przypadku człowiek dochodzi do nich na mocy dobrowolnego i świadomego wyboru" ${ }^{\prime 69}$.

W Sumie Teologicznej Tomasz, odwołując się do Augustyna, pyta: „Czy wierzyć znaczy myśleć z przyzwoleniem (woli)"70. Odpowiadając analizuje rolę rozumu i woli w odniesieniu do aktu poznawczego prawdy jeszcze nie dojrzałej. Prawdę można osiągnąć pod wpływem

\footnotetext{
${ }^{66} \mathrm{FR}, 41$.

${ }^{67} \mathrm{FR}, 41$. Papież podkreśla, że niesłusznym jest pogląd, według którego używanie kategorii filozoficznych miało służyć jedynie wyrażaniu prawd wiary.

${ }^{68} \mathrm{FR}, 42$.

${ }^{69} F R, 43$. Papież wskazuje na aktualność myśli Tomasza pisząc, że „w jego bowiem refleksji wymogi rozumu i moc wiary połączyły się w najbardziej radykalnej syntezie... potrafił on bronić radykalnie nowych treści przyniesionych przez Objawienie, nie łamiąc nigdy zasad, jakimi kieruje się rozum”, $F R, 78$. Aktualność myśli Tomasza rysuje się na tle współczesnych prądów myślowych (eklektyzm, scjentyzm, pragmatyzm, nihilizm) oderwanych od poznania świata, rzeczy i osób realnie istniejących.
}

${ }^{70}$ S. Th., II-II, q. 2, a. 1. 
zorganizowanego (naukowego) procesu poznawczego. Człowiek może jednak poznawać również pod wpływem przyzwolenia, nacisku woli by uznać za prawdę, to co zostało przez kogoś przekazane. Dzieje się to nie pod wpływem oczywistości, lecz z powodu nacisku woli nakazującej uznanie czegoś za prawdę. Akt wiary jest zatem aktem poznania, w którym pod naciskiem woli przyjmuje się, że jest tak, jak to zostało przyjęte, jak się twierdzi i dalej przekazuje. Dochodzi się do stwierdzenia, tego, czego się nie widzi i przyjęcia ze względu na chęć wyrażoną przez wolę. Chęć przyjęcia przez wolę czegoś za prawdę dokonuje się pod wpływem łaski wiary, dzięki której uznaje się za prawdę to, co Bóg człowiekowi objawił. Prawda zostaje przyjęta ze względu na autorytet Boga $^{71}$. „Tak więc cechą właściwą wierzących jest myślenie przyzwalające i tym akt wierzenia odróżnia się od wszystkich innych czynności umysłu, odnoszących się do prawdy lub fałszu"72. Różnica pomiędzy aktem wiary a każdym innym opartym na myśleniu przyzwalającym polega na tym, że w akcie wiary człowiek oczekuje na sprawdzenie przyjętej prawdy oraz osobistą wizję w wieczności. ${ }^{73}$ Tomasz konkluduje pisząc, że „wierzyć to akt rozumu pobudzonego przez wolę do uznania: a więc akt wiary pochodzi i od woli i od umysłu... wierzyć to akt bezpośredni umysłu, gdyż jego przedmiotem jest prawda, a ta istotnie należy do umysłu"74.

Myślenie przyzwalające polega na przyjęciu za prawdę tego, co zostało przez kogoś przekazane. W akcie wiary treści przyjmowane za prawdę mają swoje źródło w Bożym Objawieniu. Akt wiary jest zatem odpowiedzią „wyrażającą posłuszeństwo Bogu"75 , który pozwala się poznać. Wiarygodność i prawda Objawienia poświadczone są jego Boskim autorytetem. W akcie wiary człowiek akceptuje i uznaje za prawdę to, co zostało mu objawione. Rękojmię prawdy stanowi sam

\footnotetext{
${ }^{71}$ Por. M. A. Krąpiec, Filozofia w teologii. Czytając Encyklikę "Fides et Ratio”, Lublin 1999, s. 131-132.

${ }^{72}$ S. Th., II-II, q. 2, a. 1.

${ }^{73}$ M. A. KrąPIEc, Filozofia w teologii. Czytając Encyklike „Fides et Ratio”, s. 132.

${ }^{74}$ S. Th., II-II, q. 4, a. 2.

${ }^{75} \mathrm{FR}, 13$.
} 
Bóg. Rozum ludzki akceptuje to, co otrzymał w darze od Boga. Sam nie może się tego domagać. Objawienie jest darem, który pobudza do myślenia i domaga się przyjęcia w kontekście relacji międzyosobowych jako dar miłości ${ }^{76}$. Akceptacja wiary wiąże się z pragnieniem i możliwością jej poznania, stąd też odpowiedzią na dar wiary jest poszukiwanie prawdy i jej ostatecznego zrozumienia.

\section{Zakończenie}

Definicja ustawy wypracowana przez Tomasza została powszechnie zaakceptowana. W świeckiej nauce prawa pomija się przy podawaniu definicji ustawy i raczej cicho akceptuje jej pierwszy element: ordinatio rationis, aczkolwiek wobec dyskusji wokół racjonalnego ustawodawcy i nacisków grup społecznych na stanowienie prawa uwidacznia się również woluntarystyczny charakter normatywnych rozporządzeń.

Pojęcia ustawy Tomasz nie zaaplikował do ustawy kanonicznej. Twierdzenie takie opiera się na tym, iż Tomasz nigdzie wprost o tym nie napisał. Na możliwość objęcia definicją ustawy również ustawy kanonicznej wskazują jednak inne przesłanki. Pierwszą z nich jest sposób, w jaki została przez niego ujęta lex nova evangelii, którą poznaje się jedynie dzięki łasce wiary. Dodaje, że lex nova est ipsa gratia spiritus sancti, quae datur Christi fidelibus ${ }^{77}$. Bez łaski nie istnieje możliwość ujęcia lex evangelii na drodze racjonalnej Drugą jest miejsce, jakie zajmuje ona raczej w sferze mistycznej Kościoła jako duchowej wspólnoty pomiędzy Chrystusem i wierzącymi. Kolejna dotyczy odniesienia prawa kanonicznego do społecznościowego wymiaru Kościoła w funkcji porządkującej wymagania wynikające z lex nova. Jako taka weszła na stałe do tradycji kanonistycznej, w której pochodzące od Bellarmina określenie Kościoła w funkcji apologetycznej w stosunku do państwa takiej obecności sprzyjało.

Przyglądając się współczesnym definicjom ustawy kościelnej można bez trudu zauważyć, że koncentrują się raczej wokół jej elementów zewnętrznych, charakterystycznych dla ustawy jako aktu

\footnotetext{
${ }^{76}$ Por. FR, 13; 15.

${ }^{77}$ I-II, q. 106, a. 1.
} 
normatywnego powszechnie przyjętego. W mniejszym stopniu akcentują jej elementy wewnętrzne. Te definicje w punkcie wyjścia określają ustawę kanoniczną jako ordinatio fidei. Należy jednak podkreślić, że zastąpienie ordinatio rationis ma swoje źródło w fakcie nowego ujmowania roli rozumu w poznaniu rzeczywistości i jej odniesienia do prawa, gdzie rozum to nie recta ratio lecz ratio creatrix. Dla Tomasza, jak i dla całej ówczesnej chrześcijańskiej Europy rozum był zawsze rozumem oświeconym wiarą, a porządek ziemski podporządkowany ostatecznemu celowi człowieka, zbawieniu

W odmienny od Tomaszowego sposób ujmuje się prawo kanoniczne, które stanowi jedność tego co Boskie i ludzkie w ramach jednego porządku prawnego Kościoła. Ustawa kanoniczna jest wyrazem aktu wiary (rozumu i woli), poprzez który przyjmuje się za prawdę to, co zostało przez Boga objawione, a następnie w normy ujęte. Przyjęcie prawdy jest zobowiązujące, ale akt wiary pozostaje zawsze aktem ludzkiego umysłu pod wpływem woli przyzwalającej. Wiara uzasadnia ludzkie prawo kościelne, wyznacza mu kierunki w odniesieniu do celu Kościoła przez nią ujętego. Poza tym także treści prawa Bożego podlegają historycznemu rozwojowi i ich poznanie dokonuje się przez rozum pod wpływem obecnego i działającego w Kościele Ducha świętego.

Chrześcijanin żyje w określony sposób w Kościele nie ze względu na normy prawne, lecz na osobistą wiarę wyrażoną we wspólnocie. To normy wiary, a nie normy ustawy mają przede wszystkim swoje odniesienie do ordinatio fidei. Ustawa jest dziełem człowieka, w której zawarte są $\mathrm{w}$ formie zobowiązującej normy wiary. Rozum jest środkiem przekazu wiary, którą odczytuje i historycznie uobecnia w normie prawnej.

Rozważania dotyczące ordinatio rationis czy ordinatio fidei biorą pod uwagę sposób poznania ratio divina jako przyczyny istnienia wszystkich rzeczy. Na zewnątrz ujawnia się ona jako ordinatio, w której człowiek uczestniczy nie na mocy rozumowego dyskursu, lecz dzięki łasce wiary w oparciu o przyjęcie Boskiego autorytetu. Nie można jednak deprecjonować roli ludzkiego rozumu, gdyż akt wiary to akt bezpośredni umysłu. Przedmiotem aktu wiary jest prawda rozumiana jako locutio Dei attestans. I tę rolę rozumu należy mieć 
na uwadze, gdy określa się ustawę kanoniczną jako ordinatio fidei. Jego rola nie polega jedynie na historycznym kształtowaniu wymagań prawa Bożego. W ustawie kanonicznej odgrywa rolę nie tylko droga poznania rozporządzenia prawa Bożego, ale również siła przekonania na drodze rozumnej akceptacji wzbudzonej przez wolę pod wpływem wiary. Ten proces urzeczywistnia się również w ustawie kanonicznej. Przylgnięcie zaś do Prawdy dokonuje się w bezinteresownej miłości, która w ustawie powinna się wyrażać.

\section{Dilemmas concerning the canon law (I) - ordinatio rationis or fidei in the light of Encyclical Fides et ratio}

The content of the study are dilemmas connected with the definition of the act proposed by St. Thomas Acquinas. The attention was focused on its first element, which is ordinatio. Acknowledging the definition of the canon law understood as ordination fidei does not equal the passive role of reason in accepting it, since the act of faith remains the act of human reason, whose object is the truth accepted as such by virtue of God's authority. The role of reason does not come down only to historical perception and shaping the demands of God's law. The canon law, which is merely a human, legally binding way of passing on faith, is the token of this act, through which one accepts what was revealed by God and then expresses in norms as the truth. Ordinatio fidei finds its place in the norm of faith (fides qua) and its acceptance (fides quae) and ordination rationis in the process of expressing it by means of a tool which is a normative act in the form of legal regulation.

SŁoWA KLUCzowe: św. Tomasz, lex, lex canonica, ordinatio rationis, ordinatio fidei, Encyklika Fides et ratio

Keywords: s. Thomas, lex, lex canonica, ordinatio rationis, ordinatio fidei, Encyclical Fides et ratio

\section{Nota o Autorze:}

O. DR hAB. Tomasz Galkowski C.P., PROF. UKSW - profesor nadzwyczajny na Wydziale Prawa Kanonicznego UKSW w Warszawie, kierownik zakładu Teorii Prawa Kanonicznego w katedrze Teorii i Norm Ogólnych Prawa Kanonicznego. 